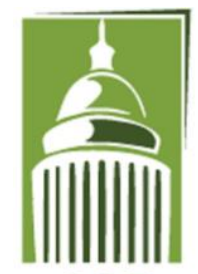

AR F

\section{Global Proceedings Repository \\ American Research Foundation}

ISSN 2476-017X

Available online at http://proceedings.sriweb.org

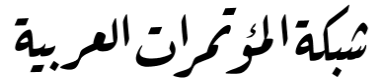

http://arab.kmshare.net/

The First International Scientific Conference

Iraqi Academic Union / Center for Strategic and Academic Development Under the Title "Humanities and Pure Sciences: Vision towards Contemporary

Education"

11-12 February 2019, University of Duhok - Iraq

$$
\begin{aligned}
& \text { المؤتمر العلمي الدولي الاول تحت شعار }
\end{aligned}
$$

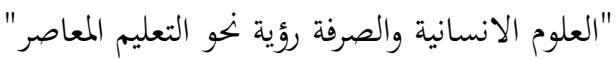

$$
\begin{aligned}
& \text { 2019 -11-12- شباط } \\
& \text { في رحاب كلية التربية الاساسية/جامعة دهوك/العراق }
\end{aligned}
$$

http://conference.iraqiacademics.iq

\title{
Romanticizing Death and Suicide in Sara Teasdale's Poetry
}

Shaymaa Zuhair Al-Wattar

College of Arts, University of Mosul, Mosul, Iraq. shaymaa_zuhair@yahoo.com

\begin{abstract}
:
Fascination with death was a lasting theme in poetry. For centuries death's inevitability, finality and mystery, captivate the imagination of many poets and elicit deep emotions. For some poets this fascination grew to be a romanticization not only of death but also of suicide due to many factors. The factors interpersonal difficulties and tragedies, psychiatric disorder, aging and the relentless search for peace, serenity, and immortality, prove to be critical.

Women poets in particular are more attracted to death and suicide, some of them went even further as they chose the final act of self-destructing, suicide. The linage of suicide in American women poets began with Sara Teasdale. The poet romanticizes death early in her poetry as death castes its shadow over some of her poems. As she grew older, she became more depressed and a sadder person hence her poems became much darker, and heavy with weight of the premonition of death.

This paper shed the light on Sara Teasdale's poetry that manifested her early fascination with death along with motivating factors that led to the rapid progress of this
\end{abstract}




\section{Global Proceedings Repository \\ American Research Foundation}

ISSN 2476-017X

Available online at http://proceedings.sriweb.org

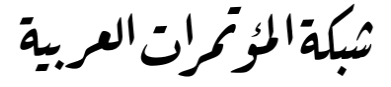

http://arab.kmshare.net/

A R F

fascination to romanticization not only of death but of suicide that she turned to as her final resort.

Key Words: Sara Teasdale, Poetry, Romanticizing Death and Suicide.

\section{Introduction}

The fascination with death and suicide and even romanticizing them run through the poetry of many poets. The idea of death hunted poets through ages. The inevitability of death, its finality and mystery, elicit deep and varied emotions. Poets reflect on death and nearly every poet wrote at least a poem or two about death, however, their approaches were as different as their attitudes towards death. The overwhelming nature of death, its obscurity, and inevitable, often sudden arrival, develop different reactions. The idea that death can end one's life at any moment and when he/she is least expecting, is exasperating.

This lack of control over one's own fate led many people, including poets, to try desperately control their fates and hence to choose when, where and how to end their own lives. This idea has special gravity and suicide turned to be a very tempting yet all the same an appalling choice. However, this raises the question: could this idea be the sole death-drive? Or are there other factors as well as deeply rooted problems that motivate and even hasten the launch of such an eerie act of self-destruction?

Many studies have been conducted as this intriguing question occupies the minds of psychologists for years. Their findings reveal that in many cases there is a significant relation between suicide and mental illness. However, what is interesting is the proven fact that gender and creativity are also related to mental illness and suicide.

Writers and poets are more likely to contract mental illness, thus they are at high risk for suicide. Poets tend to have among the highest rates of depression and psychosis than other fiction and nonfiction writers due to their delicate nature, high sensitivity, and creativity. (Kaufman, 2001, p. 38.)However all writers and poets alike are always at risks of rejection and/or severe criticism. The psychologist David Lester in his book, Suicide and the Creative Arts(2009), states these risks as follows: First, the literary product of the writer and poet that is "intensely personal document... must be submitted to others for acceptance. Few writers have never suffered a rejection. Most endure many rejections before a work is accepted. This rejection is not merely a minor setback in a career. It is a rejection of an intensely personal product. "The second risk is the critics' reviews as they "are often critical. Critics have to be negative. Even when praising a work they think highly of, they typically find some small area to criticize." (Stack and Lester, 2009, p. 193) 


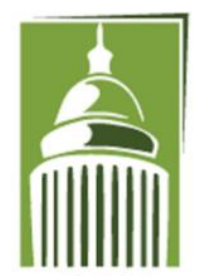

ARF

\section{Global Proceedings Repository \\ American Research Foundation}

ISSN 2476-017X

Available online at http://proceedings.sriweb.org

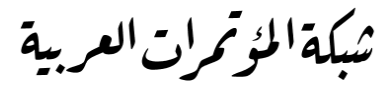

http://arab.kmshare.net/

Therefore, the literary creations of the writers and poets are always subject to the scrutinizing eyes of the public as well as the critics. In their work, which is mostly highly personal, they reveal themselves, their deep inner feelings, yet if the work is negatively received by critics, and public, to some of them this could be devastating. Hence, the poets' literary productions, which are the most delicate, yet intense expressions of human experiences and emotions, represent a valuable source for the psychologists and researchers' studies.

In their poems, most of the poets are quite articulated about their suffering, they tend to tackle their problems like depression, mania, alcoholism and other kinds of problems, openly. This honesty and candidness pave the way to talk about a topic that was considered for a long time as a taboo that is suicide. Many poets did not only write about suicide, but they domesticated and even romanticized suicide. While others, fairly well-known poets went even further as they chose suicide as the final resort, including Vachel Lindsay (1931), Hart Crane (1932), Sara Teasdale (1933), Sylvia Plath (1963), Randall Jarrell(1965), John Berryman (1972), and Anne Sexton (1973), to mention a few.

While the reasons for poets' suicides are varied, creativity and mental illness prove to play a substantial role in the poets' final act of self-destruction. Sandra M. Gilbert, a distinguished poet and critic, suggests that poets suffer a conflict between what "Freud called the "death instinct" or "drive" and the adult self's desire to survive even under threatening circumstances". This conflict between "to be and not to be is inflected by history, by culture, and by gender"(Gilbert, 2005, p. 248) Gender, in particular, attracts the attention of psychologists and scholars and studies reveal that women are more attracted to death than men. David McClelland an eminent psychologist suggested, "not all people fear death. Indeed, some people, often women, actually seem to look forward to death, with a sense of excitement as well as fear, as if death could be an unconscious equivalent for the final sexual union with the ideal mate".(Stack and Lester, 2009, p. 150)

Creativity, gender, mental illness, and suicide are all linked and many studies were conducted to investigate this linkage. The findings reveal that creative female writers and especially female poets were significantly more likely to suffer from mental illness than male writers and poets. (Kaufman and Baer, 2002, p.273) These findings create a challenge to discover the factors that make the female poets more susceptible to mental illness as well as the reasons which lurk behind their tendency to commit suicide.

Creativity, or to be more specific hindered creativity, proves to be an essential factor as mental illness that plagues female poets far more than women in general. Being a woman in a society dominated by males is nerve-racking. The opportunities for women in general are few, and even fewer if these women were creative. However, it was the 


\section{Global Proceedings Repository \\ American Research Foundation}

ISSN 2476-017X

Available online at http://proceedings.sriweb.org

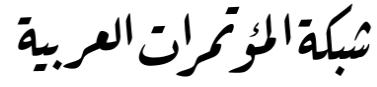

http://arab.kmshare.net/

AR F

creative writing that provided the shelter for these women; in their literary works they can attain the freedom the society denies them.

D. K. Simonton, in his Greatness: Who Makes History and Why (1994), stated, "until recently, creative writing was the only area where women could really shine", he added "male domination of resources alone could explain why women have the best prospects in literature. It doesn't require a well-equipped laboratory, a full orchestra, or a large block of marble to write a masterpiece of fiction or poetry". (Simonton,1994, p.36) Still, even in this limited area, male domination curbs the women's creativity. They paid a high price for their creativity as they were denied the recognition they deserve and suffer from the harsh criticism and prejudice against their work, and definitely not all of them were able to deal with it and survive.

Hindered creativity as well as the difficulties they face with their artistic careers increases the chances of developing a psychiatric disorder, other factors of personal nature proved to be critical as well. The lack of marital stability, separation or divorce, a personal tragedy like the loss of a parent, a child, a beloved, or a very close friend, among others, motivate the mental illness, which might lead eventually to suicide. Adding to the social expectations and the prescribed gender role of the women as a caretaker, wife and a mother, a reliable study of contemporary women creative writers revealed that these women exhibit the "same personality characteristics and drive as men writers, but they also experience the conflict of being women and reconciling family duties with their creative work". (Kaufman and Baer,2002, p. 281)

As Anne Sexton, a prominent American poet puts it briefly, "a poet/ a lady of evil luck" (Sexton, 2001, p. 429). Being a woman poet, she is already at a higher risk for mental illness than other creative women writers and the combined weight of one or more of above-mentioned factors may create a poet who is likely to succumb to mental illness and even suicide. The main illnesses that threaten women poets are mania and depression. Many well-known American women poets, Sara Teasdale(1884 - 1933), Edna St Vincent Millay(1892 -1950), Elizabeth Bishop(1911 - 1979), Louise Bogan(1897 -1970), Anne Sexton(1928 - 1974), and Sylvia Plath( 1932 - 1963) were only a few of the many poets who suffer from depressive illnesses, especially manicdepression. Teasdale, Plath, and Sexton had tragically ended their lives by suicide. (Crawford, 2006, pp. 193-4)

Both Sylvia Plath and Anne Sexton were influenced by Sara Teasdale, and many younger women poets were influenced by those three poets. It is worth mentioning that the linage of suicide would have continued to take the lives of many young women poets, but there was a cry of awakening. A serious drive to resist the romantic obsession with victimization and death is to be strong, and to do the best they can to get their rightful 


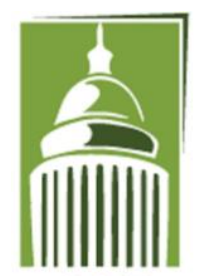

ARF

\section{Global Proceedings Repository \\ American Research Foundation}

ISSN 2476-017X

Available online at http://proceedings.sriweb.org

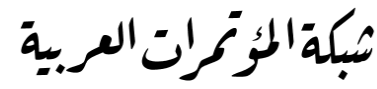

http://arab.kmshare.net/

place as respectful and influential creative women poets. Indeed, this saves the lives of so many young poets who were motivated by such words as those of Adrienne Rich who angrily reacted to the suicide of her contemporary poet Anne Sexton, saying: "We have had enough suicidal women poets, enough suicidal women, enough of selfdestructiveness as the sole form of violence permitted to women. ... When we begin to feel compassion for ourselves and each other instead of for our rapists, we will begin to be immune to suicide." (Swiontkowski, 2003, p. 86)

Fascination with death and suicide, and even romanticizing them runs through the poetry of many women poets, whatever their ultimate ends came to be. Although this fascination might seem dark, frightening, weird, and even morbid, yet it remains an enduring theme in their poetry. Many women poets state with brutal honesty their wishes for self-annihilation as well as a romantic attraction to the idea of choosing or deciding their own ends. The lineage of suicide in American women poets started with Sara Teasdale, a notable and accomplished poet who romanticized death and suicide mainly in her later poems, and who eventually committed suicide at the age of forty-eight.

\section{Sara Teasdale: Fascination with death and suicide}

The winner of the Columbia University Poetry Society Prize (forerunner of the Pulitzer Prize for poetry) in 1918 and before that the annual prize of the Poetry Society of America in 1917, Sara Teasdale was an important voice of American women's poetry in the early 20th century. She left seven volumes of poetry, two anthologies, The Answering Voice and Stars To-Night, besides a book of children's poetry. Her work is best described by comparing it to "ascending terraces on the side of that mountain, whose summit, the absolute beauty, no mortal can ever reach." (Carpenter, 1960, p. 131)

Sadly, her great poetic output and mesmerizing volumes of poetry she left behind, were overshadow by the fame of her dramatic death. Her suicide was a real shock, but expected. A pen picture of Sara Teasdale portrayed her as a "quiet, gentle voiced lady. . . . a woman of poise and a poet of great distinction. . . A wise heart, vision, a sense of beauty in simple things; these are hers, and added to them an intellectual grasp of the technique of verse which gives her the ability to conceive in sentiment and execute in art."(Rittenhouse n.d. ,p.11)

As a poet, she was very talented and her poems are really little short of magical. They are delicate and lyrical in nature, with simple expressions, while her major themes are love, joy, nature's beauty, loss, grief, and death. The poems are truly a genuine and honest record of her thoughts, feelings and experiences as for her "poems are written because of a state of emotional irritation. It may be present for some time before the poet is conscious of what is tormenting him. The irritation springs, probably, from 


\section{Global Proceedings Repository \\ American Research Foundation}

ISSN 2476-017X

Available online at http://proceedings.sriweb.org

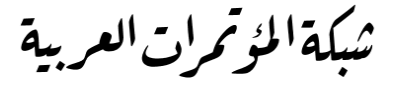

http://arab.kmshare.net/

AR F

subconscious combinations of partly forgotten thoughts and feelings. Coming together, like electrical currents in a thunderstorm, they produce a poem. A poem springs from emotions produced by an actual experience, or almost as forcefully, from those caused by an imaginary experience. In either case, the poem is written to free the poet from an emotional burden." (Carpenter,1960, pp.9-10)

In her early poetry, she was passionately concerned with love and the beauty of nature; she was able to see beauty in just about everything. However, her haunting poems tell another story showing signs of depression, frustration, and fascination with death. They progressively grow darker and darker, and with the passing of time, she changed the face of her poetry. She abandoned the imaginary, even girlish dreams and the romantic idealization of love and beauty of her very early poems and turned to more austere and mature thoughts, mainly of death and even suicide.

Her poems are a genuine reflection of the poet herself, Sara Teasdale herself says "I try to say what moves me-I never care to surprise my reader." (Kimmelman, 2005, p. 492) A penetrating reading of her poems provides some tell-tale signs not only her emotional but psychological and mental state as well. Thus, what is shocking is her early preoccupation with death and even suicide at a very early age. In 1911, breaking the social codes about depression and self-destructiveness, she wrote "I Shall Not Care":

WHEN I am dead and over me bright April

Shakes out her rain-drenched hair,

Tho' you should lean above me broken-hearted,

I shall not care.

I shall have peace, as leafy trees are peaceful

When rain bends down the bough,

And I shall be more silent and cold-hearted

Than you are now. (Teasdale, 1937, p.54)

The poem is dark and mournful, yet it is so romantic. Sara Teasdale is highly romantic and being deeply influenced by the nineteenth century poets, she wrote this poem "in the vein of Christina Rossetti's early work, she imagines herself in her grave and at peace, indifferent to the grieving lover who now must suffer because he did not pay attention to her in life." (Drake, 1979, p. 73) Also, the poem is intensely personal and Sara Teasdale herself is speaking here, and not using any of her early personas. The poet's own suffering and bitterness are portrayed as she was in love, but the relationship failed. The speaker is really so innocent and even girlish as she thought that the man who neglected her while she was alive is going to feel sorry and would suffer after her death which reveals how inexperienced the poet really is both in love and with men. Once her 


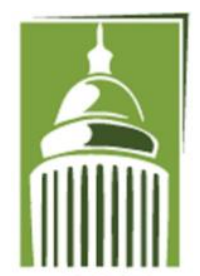

ARF

\section{Global Proceedings Repository \\ American Research Foundation}

ISSN 2476-017X

Available online at http://proceedings.sriweb.org

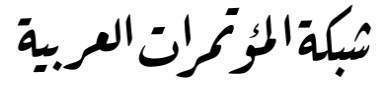

http://arab.kmshare.net/

first romance failed she was not only sad but also frustrated and instantly turned to the idea of suicide.

However, the essence of her problems could be traced to her early years. Being the late-arriving child of a wealthy family, and sixteen years younger than her closest sibling, made her the centre of attention. Her family was extremely over-protective of their youngest daughter and constantly worried about her frail health - although she was not suffering from any serious problem. She was made to believe at early age that she is vulnerable and sickly, even when she was perfectly well. The morbid concern for her physical well-being weakened her in mind and spirit and affected her mental health when she grew older. (Mueller, 2009 , p.10).

In her poetry death always casts its shadow. She frequently uses "death imagery" represented by words like night, midnight, dusk, twilight, and gray. Reading her poems, one is struck by the repetition of these words are used from her very early poems, indicating the mounting sense of depression that came to haunt her.

Depression is actually a characteristic of 20th-century American women poets in general including Sara Teasdale. Even if an accurate diagnosis of her psychiatric condition is not possible' her depressed mood is presented clearly in her poems. Unquestionably, Sara Teasdale's childhood is not really the only reason behind her depression and early attraction to death that came to surface at an early age, it simply triggered her depression, and then other factors contributed and even accelerated it. Eventually the combined heavy weight of many factors is what led her to commit suicide.

One of the factors and may be the most critical is being a woman poet; this placed her at a higher risk for depression and other emotional disorders. As it is discussed earlier, creativity increases the chances of developing a psychiatric disorder, so the poet's strong investment in her writing and her concern over her worth as a poet may have predisposed her to depression. Added to that is her marriage and the agonizing inner conflict between being a renowned poet and her prescribed gender role of being a wife and a mother.

Due to her upbringing, she felt that she had to get married, despite her deep blazing desires for freedom and isolation and more importantly for self-fulfillment as poet. This causes a split in her personality and her" divided-self" was best described as " a personality ready for self-fulfillment, rich in outgoing emotion, sensuous, and keenly sensitive, attuned to esthetic rather than moral imperatives, but stricken with a paralyzing obedience to the rigorous proprieties imposed on her in childhood, mainly by her mother". Sara Teasdale herself wrote in 1914 "I must marry, for at bottom I am a mother more intensely than I am a lover." (Walker, 1991, pp. 55, 57) 


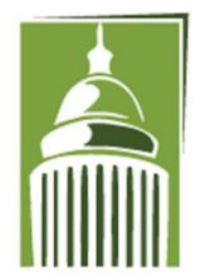

ARF

\section{Global Proceedings Repository \\ American Research Foundation}

ISSN 2476-017X

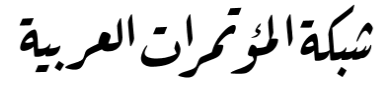

http://arab.kmshare.net/

Available online at http://proceedings.sriweb.org

Sara Teasdale romanticized marriage in an unrealistic way. She eventually married Ernst Filsinger, a well-educated businessman in1914 shortly after their first meeting. It is noteworthy that before she met Ernst Filsinger, she had an intense emotional relation with the poet Vachel Lindsay, but their love affairs failed due to lack of financial stability and her assumption that he was not all what she want aspired for.

During the short courtship before their marriage, Sara Teasdale did not write any poetry and she worried that the joy of marriage might" rob her of creativity" as, "...she had developed a theory that "song" (as she called her verse) was the transmutation of pain, particularly, the pain of loneliness and unreturned love. If she were to become ideally happy, what would happen to her creativity, which would have no frustration to feed on?". ( Drake,1979, p. 142) However, her happiness, or what she considered ideal happiness, did not last long. Her marriage proved to be but a hasty decision that she was to question for the rest of her life. The marriage and the accompanied stress of marriage responsibilities, family duties, and social expectations, as well as her aspirations and constant yearning for freedom and solitude frustrated all her dreams about marriage and love. This frustration was reflected in her volume Rivers to the Sea (1915).

In Rivers to the Sea, Sara Teasdale abandons her early persona and uses her own voice to depict her enduring struggle. The poet skillfully and beautifully gathers brightness and darkness revealing two sides of marriage, the bright side represented by love and the present of a lover, and the dark side that is created by the frustration she felt due to the ruthless realities of life after marriage and her inability to cope with the new life.

Being a woman poet, she was torn between her deep desire for freedom, for solitude, and for being a renowned poet on the one hand, and her prescribed gender role of being a wife and a mother on the other. She sought freedom through love, marriage and motherhood, however there is always the irresistible magnetism of solitude and freedom causing a split in her personality, hence the poet presented contradictory selfimages.

Her poems in general reflect a tension of considerable interest to her generation and of continuing interest to the present generation: the modern problem of feminine identity-formation, in other words the problem of balancing autonomy with affiliation, freedom with love. (Walker, 1991,p.45) The best poem to represent this problem is "I am not Yours".

From the very first line of this poem the inner conflict is presented the speaker states, "I am not yours, not lost in you, /Not lost, although I long to be."( (Teasdale, 1937, p.70)Obviously, she wants to fall in love but there is a sense of fear as falling deeply in love is equated to compromising her freedom and sacrificing her identity in this relation. 


\section{Global Proceedings Repository \\ American Research Foundation}

ISSN 2476-017X

Available online at http://proceedings.sriweb.org

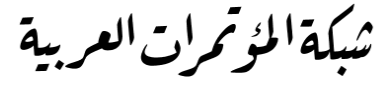

http://arab.kmshare.net/

Her decision is to follow her heart despite the high price she should pay which is to lose her true identity:" Oh plunge me deep in love -- put out/ My senses, leave me deaf and blind,". The identity crisis and the problem of balancing true love and affiliation, is the real ordeal of the speaker. She seems unable to grasp the fact that to love someone she does not need to sacrifice her identity and dissolve entirely into that of her lover; she needs to differentiate between true love and affiliation.

It is worth mentioning that Sara Teasdale is romantic poet par excellence. In her early poetry she was mesmerized by love and the beauty of nature, her flamboyant personality reflected in her delightful poetry, despite recurrent touches of sadness, bitterness, and domestication of death. She was ceaselessly and restlessly searching and yearning for romantic love she dreamed of having.Yet her dreams were crushed as love and life could not reach out to her expectations. She found herself striving to come to terms with life and to find a resolution for the sense of unease with the new realities of life imposed on her after marriage. As time passed, her poems began to show an air of resignation that became more and more pronounced. She began to feel that she is lonely and that she had to give up everything she ever desired. The harsh and bitter lessons of life change her and frustration began to cast its shadow over her poems giving way to depression and a serious preoccupation with death.

In her poem "The Answer", the poet tackles death again but now she is clearly not afraid of death but willingly accepting it. She is already in her grave as her body "Puts off the red and white", but she resentfully rejects people's pity, the natural reaction to death. For her they simply cannot comprehend death the way she does, her concept of death is definitely not traditional. According to her there should be no pity, no fear but a calm acceptance of death. To die does not necessarily mean that she is going to be defeated, the flame in her, her hidden strength is going to emerge, and even if she turns to dust, she will find a voice to answer them aloud:

"Be still, I am content,

Take back your poor compassion,

Joy was a flame in me

Too steady to destroy;

Lithe as a bending reed

Loving the storm that sways her--

I found more joy in sorrow

Than you could find in joy. " (Teasdale, 1937, p.74)

She is simply content and as she is used to gladly undertake life's adversity, she will embrace death. 


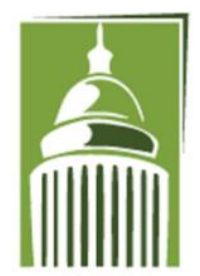

AR F

\section{Global Proceedings Repository \\ American Research Foundation}

ISSN 2476-017X

Available online at http://proceedings.sriweb.org

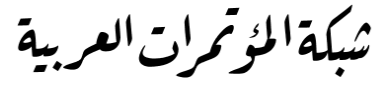

http://arab.kmshare.net/

The poet is obsessed with "pity" and her prediction of the people's reaction suggest that her death is just impending, and it could be a tell-tale sign to her own tragic death by suicide. While in "Testament", the poet unexpectedly and to some extent with shocking openness declares:

..., "I will take my life

And throw it away;

I who was fire and song

Will turn to clay." (Teasdale, 1915, p.118)

Although it is not the first time Sara Teasdale entertains the idea of suicide, here it is rather so sudden and direct. However, the end of the poem is not that shocking as its beginning when, the poet castes away the whole idea of throwing her life away and subdue embracing her fate with modesty and complete acceptance, saying:

..., "Oh who am I

To scorn God to his face?

I will bow my head and stay

And suffer with my race."

The ending of the poem is intriguing, after two blazing stanzas in which she is decisive about her end, she had a sudden flip of the heart after she heard "Like the inland sound of the sea, / The hushed and terrible sob/ Of all humanity." Sympathizing with the member of her race, she immediately changes her mind and decides to accept her fate calmly like all humanity.

The whole volume, Rivers to the Sea, demonstrates a skillful balance between darkness and light, sadness and joy, hope and frustration. Successfully, it paves the way for Sara Teasdale to write more exceptionally good lyrics and for her skill to grow tremendously. Her next collections manifest the poet's artistic maturity and her evolving to a mature woman has been hardened by life experiences. Yet the poet continues to express her ideas and emotion candidly in the simplest form of English lyric poetry.

Sara Teasdale became an icon of the new romantic impulse after her age. In Love Songs and despite her idealization of love and beauty, the poems reflect the poet's deep desire to be independent and set forth her frustration and depression over the realization that her expectations for marriage had fallen short. It is clear that she failed to reconcile her early girlish romantic fantasies with the harsh realities of married life. The volume contains a small new set of six poems entitled "Interlude: Songs out of Sorrow", their impetus was the self-scrutiny of her present life and they were the first foreshadowing of the mood that would gradually spread to dominate her work. (Drake, 1979, p. 162)

After marriage and although she was granted the highest, unprecedented honorwinning the nation's highest honor as her Love Songs was chosen as the best book 


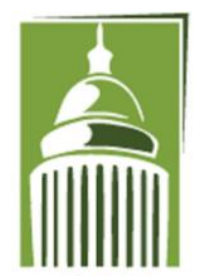

ARF

\section{Global Proceedings Repository \\ American Research Foundation}

ISSN 2476-017X

Available online at http://proceedings.sriweb.org

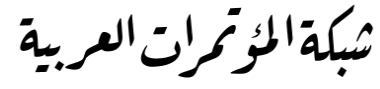

http://arab.kmshare.net/

of poetry for the year by Columbia University, the precursor to the Pulitzer Prize for Poetry- Sara Teasdale was not overwhelmed with joy. In fact, her life began to sour; it was a kind of self-inflicting suffering. She was constantly anxious, and restless due to her inability to cope with the realities of her new life and her constant retreat to the past when she was young dreaming of bright future which might offer her many choices. She was unwilling to accept her life and kept searching for something, the one thing that is going to make her fulfilled, and unquestionably, it was not marriage.

Sara Teasdale's choices made her stressed out. She questioned every life defining decision she made starting with her hasty marriage, the person she married, the abortion she had in the early years of her marriage and so on. Her emotions were unstable, her temperament was too nervous and she developed physical illness as the outcome of this stress, she began to retreat from life and from her husband as well and withdraw gradually into herself.

She continued to write but her output was slow and her poems were "unflinching studies of her losses, and at times even the poetry seemed a worthless and littleunderstood residue of a life that had been spent in a slow, silent bleeding to death." (Drake, 1979, p. 182) There was a progressive and increasing tendency to equate love with death, though it is not new in her poetry.

The next volume to publish is Flame and Shadow in 1920; it is situated midway between her early romantic volumes dealing with love and the beauty of nature and her later grimmer volumes overshadowed by death. The poet displayed her artistic maturity and her skill for arranging her poems so that there will be a balance between the flames of beauty and love, and the gathering shadows of death. From the first poem, "Blue Squills," the poet stated a conflict between the flame of beauty and the shadow of death:

Oh burn me with your beauty, then,

Oh hurt me, tree and flower,

Lest in the end death try to take

Even this glistening hour. (Teasdale, 1937, p.115)

As she attempts to balance the flame and the shadow, she is exalted in beauty and the flame, saying in "August Moonrise":

O Beauty, out of many a cup

You have made me drunk and wild

Ever since I was a child. (Teasdale, 1937, p.118)

In addition, in another poem titled "The Voice" she stresses that it is imperative for everybody to:

Forever Seek for Beauty, she only

Fights with man against Death! (Teasdale, 1937, p.123) 


\section{Global Proceedings Repository \\ American Research Foundation}

ISSN 2476-017X

Available online at http://proceedings.sriweb.org

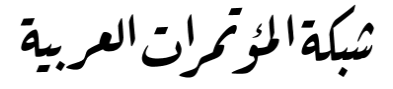

http://arab.kmshare.net/

AR F

Then the shadow came, first there is an air of resignation dominated the lines of her poem "I Have Loved Hours at Sea":

I have loved much and been loved deeply --

Oh when my spirit's fire burns low,

Leave me the darkness and the stillness,

I shall be tired and glad to go. (Teasdale, 1937, p.117)

In the last poem, "The Wind in the Hemlock", the poet wonders passionately:

What has man done that only he

Is slave to death -- so brutally

Beaten back into the earth

Impatient for him since his birth ? (Teasdale, 1937, p.159)

The poet passionately speaking about death as a curse, she contends that everybody is doomed to die. The enslavement to this fate of the inevitable death, frustrate her, as she is utterly powerless.

In this volume there is a smooth progression from affirmation of beauty through pessimistic meditation on death to a qualified reaffirmation. (Drake, 1979, p. 203) She is obsessed with death; death dominates her poems, side by side with love themes continuing in the poems. However, her Romanticism was tempered, while themes like sorrow, loss, the ruthless passing of time and the inevitable ending, began to prevail and even they turn to be the dominant strains in her last two volumes, Dark of the Moon (1926) and Strange Victory (1933).

With Dark of the Moon, Sara Teasdale's artistic and spiritual maturity reaches its fullest blossom, the poems were" enriched with an austerity, a nobleness, a resignation with no self-pity and no bitterness; they are stripped down to the very essence of wisdom born out of suffering. Having drunk deeply from the cup of beauty and love in rapturous delight, the poet now turns her thoughts irrevocably to death; where autumn was once a whisper of coming loss, now the promise is fulfilled; now the winter landscape is a certain and inescapable thing. " (Carpenter, 1960, p.344)

The poems in this volume reflect the poet's changing mood, and personal anguish bleeds through almost all these poems, depression, and darkness are taking over while positive emotions like love and the adoration of beauty and nature were decreasing. The reasons for such a change are varied; it could be the heavy burden of life mundane realities and the poet's frail health, which is mainly a symptom of depression. In addition, the poet deep, passionate veneration of beauty and love gave way to frustration, depression, and increasing fascination with death.

Furthermore, her constant yearning for solitude proves to be a greater factor in her life. As she declares earlier in "Morning Song", from Flame and Shadow, "Only the 


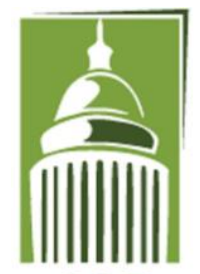

A R F

\section{Global Proceedings Repository \\ American Research Foundation}

ISSN 2476-017X

Available online at http://proceedings.sriweb.org

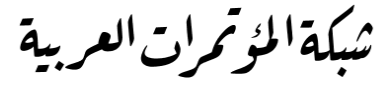

http://arab.kmshare.net/

lonely are free", (Teasdale, 1937, p.141) in her poems from Dark of the Moon, she developed this idea profoundly. Her early conflicting desire between solitude and love is presented again but now it is so clear that love is losing it considerable place. Formerly, she sought freedom through love while now she is simply casting love away in favor of solitude- though the volume included few love poems at the end. In "The Solitary", she summarized what she felt genuinely, saying:

My heart has grown rich with the passing of years,

I have less need now than when I was young

To share myself with every comer

Or shape my thoughts into words with my tongue. (Teasdale, 1937, p.179)

While in "A Reply", a poem from the section called The Crystal Gazer, the poet stated firmly:

There are no highroads to my heart;

The gates are locked, they will not stir

For any ardent traveler. (Teasdale, 1937, p.181)

It is worth mentioning that Sara Teasdale withdrew from life gradually and sunk more and more in deep depression for her marriage, relationships and career became too demanding. She yearned for solitude so that she might be free to create her poetry in isolation. Freedom is sought through death, earlier in "At Midnight" from Flame and Shadow death is presented as a release matched by nothing:

Even love that I built my spirit's house for,

Comes like a brooding and a baffled guest,

And music and men's praise and even laughter

Are not so good as rest. (Teasdale, 1937, p.156)

While in "The Flight", the final poem from Dark of the Moon, she accepts death with such a shocking and chilling ease that almost predicates her ultimate suicide:

We are like eagles,

But when Death harries us,

Human and humbled

When one of us goes,

Let the other follow

Let the flight be ended,

Let the fire blacken,

Let the book close. (Teasdale, 1937, p.193)

This calm reconciliation with eventual death is a reflection of the poet's own emotional and psychological state. She was plagued by ill health and was never getting 


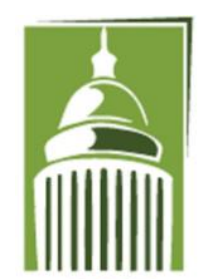

ARF

\section{Global Proceedings Repository \\ American Research Foundation}

ISSN 2476-017X

Available online at http://proceedings.sriweb.org

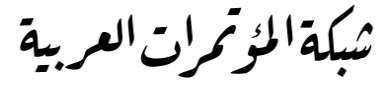

http://arab.kmshare.net/

any better and by the time she published Dark of the Moon in 1926, her marriage was beyond repaired. Reading her love poems it is so obvious that she did love her husband but she was unable to share her life with him or with anyone else. She wrote, "no highly developed, thoroughly self-conscious modern woman can really give her soul and be proud of it. I used to always think that I wanted to lose myself in the man I loved. I see now that I can never do that, and that I was foolish to wish that I could ". (Quoted in Walker,1991, p. 58)

Sara Teasdale was consumed by the fear of the ultimate loss of distinctive identity, as she believed that her marriage required an absolute devotion and a slavish subordination. Ernst Filsinger is not to blame for the divorce as he proved to be " a very supportive husband, agreeing to separate hotel rooms and allowing his wife considerable independence... . However, his increasing involvement with his work and her increasing disillusionment and depression led her to withdraw further and further into herself." Thus, she filed for divorce in 1928, the divorce was granted in 1929, and she wrote feverishly "I'm a free woman. I can do anything I want". (Walker,1991, p. 58)

Ironically, despite her thrilling enthusiasm, after her divorce she did not get the freedom, the autonomy, and the serenity she deeply desired. She strongly believed that she was "self-complete as a flower or a stone", as she stated in "The Solitary," but before long life realties prove her wrong. She was so caught up in the whole idea of getting a divorce, becoming independent, isolated and regaining her lost self, that when she finally got the divorce she failed to seize the opportunity to achieve anything. Divorce brought about more agony and moral tension since it "was much like the idea of death - carefully studied and examined from every angle, inspiring fear yet attraction, as something forbidden but promising relief." (Drake,1979, P.255) Eventually, Sara Teasdale did not get the stability, the relief, or the serenity she dreamed of for years.

Unexpectedly, she was over burdened with financial difficulties, although she came from well-to-do family, and money was never an issue for her but after her divorce she was unable to maintain the life style she used to live. However, to the end of her life, she was not reduced to poverty, but the financial anxieties crushed her dreams of being self-sufficient and completely independent woman.

Her days were passing slowly and monotonously, she spent her time reading, writing letters, and resting, rarely did she go out or see people. She, who once referred to her divorce as "this tragedy behind me", was unaware that more tragedies are ahead. She lost many of her old good friends "who used to make the city a place of radiant enchantment". (Carpenter, 1960, p. 290) Eventually she, who thought that in solitude she is going find her utmost delight and self-renewal, ended up entirely alone. Eventually, she allowed a young woman to be close to her, she is Margaret Conklin 


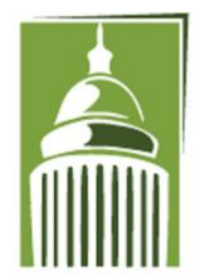

ARF

\section{Global Proceedings Repository \\ American Research Foundation}

ISSN 2476-017X

Available online at http://proceedings.sriweb.org

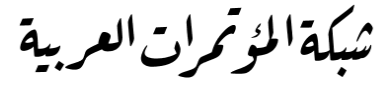

http://arab.kmshare.net/

whom she met and befriended in 1926. Margaret Conklin was young and vigorous, she may be the representation of the youth that the poet lost and yearned eagerly for, or she could be the daughter that she never had. Whatever the reason might be she stayed close to Sara Teasdale to the very end, their friendship lasted until Sara Teasdale's suicide in 1933.

The vain search for the lost youth, and the brutal realities of aging deepened her frustration and depression. She faced a hard time accepting aging and the inevitable death. The undeniable fact is that she was getting old, and "if a woman does not fear the external signs of age, she may nonetheless react with revulsion to what Freud called" an inner ice age"---the drying up of creativity." (Gilbert, 2005, p. 253). For Sara Teasdale, writing was not as easy as it used to be, her poetic output had nearly ceased, and she would spend a long time without writing a poem which depressed her even more. In her attempt to pull herself out of this depression, to occupy her mind and recapture the youth that was lost to her, she worked on an anthology titled Stars To-night: Verses New and Old for Boys and Girls (1930) which contained a charming group of poems, fifteen of which were previously published along with ten new poems.

Although the poems in Stars To-night seem to be bright and apparently suitable for young adult, dealing with nature rather than the typical themes of love or death, but the poet was disguising her feelings of insecurity, loneliness and concern with death. In her poem "Autumn Dusk", the title is not so bright or encouraging, however the poem itself is oozing strength and reinforces self-confidence:

I saw above a sea of hills

A solitary planet shine,

And there was no one near or far

To keep the world from being mine. (Teasdale, 1937, p.185)

The poem is merely four lines; it is short but eloquent.

In addition, in 1930, and to divert her attention from her increasingly frail health and the lack of emotional and financial stability, Sara Teasdale resolutely planned a biography of Christina Rossetti; it was her last project, which had never come to fruition. In 1931, she had a major setback with the suicide of one of her long -time friend, Vachel Lindsay only a month after visiting her. She was genuinely devastated by his suicide. His death is considered the mortal blow that set Sara Teasdale on her final path, which is to commit suicide in 1933. (Mueller, 2009 , p.19).Over the years Sara Teasdale was hit by one death after the other, but it was Vachel Lindsay's suicide that had the greatest effect on her as with his death her small circle of close and trusted friends diminished radically, she was lonelier than ever. 


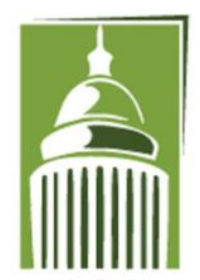

ARF

\section{Global Proceedings Repository \\ American Research Foundation}

ISSN 2476-017X

Available online at http://proceedings.sriweb.org

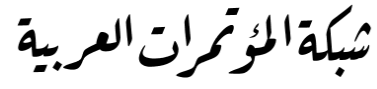

http://arab.kmshare.net/

In addition to her physical illness, her mental state was declining progressively and she suffered from a severe depression. Since 1907 until her death in 1933, Sara Teasdale she had numerous attacks of what the nineteenth century called neurastheniatypically ascribed to emotional disturbance and consequently she was given repeated rest cures, and toward the end of her life, she spent more time at various kinds of retreats than she did at home. (Walker, 1991, p.58) However, this time she seemed to lose all the will to pull herself out this state, and out of her overwhelming deep depression. Sara Teasdale felt completely helpless as she was watching her life spinning fiercely out of control. The failure of her marriage, the tragic loss of many of her close friends, the crush of her dreams of independence and freedom, the ruthless drying up of her creativity which led to a sever writer's block are few of many factors that motivated her final act of self-distracting.

Nevertheless, being chronically depressed, and consumed by the fear of her physical illness played a major role in her suicide. There is some evidence that she was actually terrified of the possibility of having a stroke just like the one that had killed her friend Amy Lowell in 1925 and disabled her brother. The progress of her illness hastens her decision as a blood vessel broke in her hand she took it as a sign of the end. On January 29, 1933, she took an overdose of sleeping pills, and when she was found by her nurse it was too late to rescue her. (Walker, 1991, p.59)

The poet's desire to control her own life and destiny proved to be an essential factor in her last act of self-distraction. The whole notion of controlling one's own life and fate is fascinated, and what is more alluring is to control one's own end, not to wait but to choose the way and the time she desired to end her life. With the mounting of the problems, illness and the repeated disappointments, the poet ultimately chose her own death.

Sara Teasdale's despair is best summarizing by William Drake in his book Sara Teasdale: Woman and Poet, he said that life "had destroyed her girlish ideals one by one, and instead had brought her a failed marriage, an abortion, ill health, and a loss of the ecstasy that she believed to be one of the chief justifications for living." Whatever her death-drive might be, he suggested that her suicide was expected as the poems of her final period, from late 1930 until her death in 1933, are "emotional accounts of the resignation and welcome Sara felt for death. Her poems suggest that she no longer doubted whether she would take her own life; the only question was how soon."( Quoted in Olson,2004, pp.37-8)

Her poetry is a genuine embodiment of her deep agony and grief. Her poems suffused with the weight of depression and premonition of death, despite her undeniable valiant effort to keep her poems spirited and bright while her entire world was collapsing 


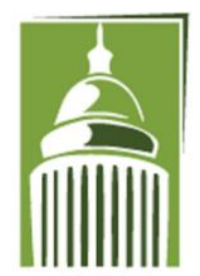

ARF

\section{Global Proceedings Repository \\ American Research Foundation}

ISSN 2476-017X

Available online at http://proceedings.sriweb.org

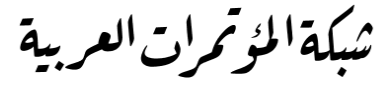

http://arab.kmshare.net/

around her. It is noteworthy that her attitude towards death changed notably, in her later volumes there is a gradual acceptance even a welcoming of death; she seemed to desire it and romanticizing the whole notion of death and the promised peaceful released that followed. She was confident that death is only a doorway to immortality that she is going to achieve through her poetry.

Right to the end, Sara Teasdale was devoted to her carrier so concern with her literary legacy, before she committed suicide, she personally selected poems for her last volume. She marked only twenty-two poems from her notebook and delegated the editing of the volume, which she entitled Strange Victory to Margaret Conklin, the volume published posthumously in 1933. It contained an elegy for Vachel Lindsay, written shortly before she committed suicide. Also it included three poems addressed to Margaret Conklin, the person who might be the only bright thing in her last years and poems about her own death like "All That was Mortal", "Since Death Brushed Past Me", "Ashes", and "Wisdom". The volume instantly earned the regard and admiration of public and critics alike, "it shows classic depth and balance". The little poem in memory of Vachel Lindsay "does indeed demonstrate that classic balance. It is at the same time a cry from the heart of the living poet, a cry for immortality." (Kumin, 1982, p. 55) It is a genuinely moving poem came right from the heavy heart of the poet, honest, direct and bitter:

"Deep in the ages", you said, "deep in the ages,"

And, "To live in mankind is far more than to live in a name."

You are deep in the ages, now, deep in the ages, You whom the world could not break, nor the years tame. (Teasdale, 1937, p.210)

For the poet, Vachel Lindsay did achieve immortality and maybe it is time for her to follow his steps and to "Fly out, fly on, eagle that is not forgotten/ Fly straight to the innermost light," and to be just like him "Free of the fret, free of the weight of living, / Bravest among the brave, gayest among the wise." The poem seems to be so personal to Sara Teasdale, one that implied her own urgent need for being free, for flying away from the "weight of living", from the burdens of life, and above all for being brave enough to take the final step towards immortality.

The volume itself, Strange Victory opens with a poem titled "Moon's Ending" preparing the readers for the elegiac mood of her poems in this whole volume especially her final poems. The poem is somber with the sense of ending, of finality however, there is still something good, the poem reads:

Moon, worn thin to the width of a quill,

In the dawn clouds flying, 


\section{Global Proceedings Repository \\ American Research Foundation}

ISSN 2476-017X

AR F
Available online at http://proceedings.sriweb.org

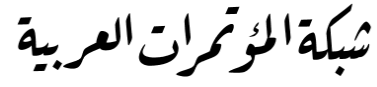

http://arab.kmshare.net/

How good to go, light into light, and still

Giving light, dying. (Teasdale, 1937, p.205)

Despite the dark topic the, lyric itself is graceful; within four lines only the poet presented her strong belief that even after the end there will be something good and satisfying.

In "Wisdom", for the poet a fundamental part of being wise is not to complain or to voice her desires, she is simply letting go silently and with no fuss:

Oh to relinquish, with no more of sound Than the bent bough's when the bright apples fall; Oh to let go, without a cry or call

That can be heard by any above ground. (Teasdale, 1937, p.205)

Her attitude towards death had undergone a substantial change, she is accepting it calmly, she simply relinquished. She even seemed to desire death, fascinated with the whole idea of the promised eternal peaceful released came along with death, this notion was a source of great consolation for the poet in her later years.

In general, the poems in this volume reveal the highest level of Sara Teasdale's artistry and her maturity even when she was in suffering and panic she was writing beautiful, poignant and calm poems. In the title poem "Strange Victory", the poet clearly announced that her "hope was lost", yet she is not defeated as there is a victory, a strange kind of victory:

To this, to this, after my hope was lost,

To this strange victory;

To find you with the living, not the dead,

To find you glad of me;

To find you wounded even less than I, (Teasdale, 1937, p.208)

She felt delighted, grateful and blessed as the one whom she cared for so much, is "with the living," and "wounded even less than" her. Reading the poem, one is left with a perception, if not convinced, that she is no longer among the living especially with her early confession from the very first line that she lost hope and her final lines"After the battle to have found your voice/ Lifted above the slain." It is noteworthy that in the end she writes, "to have found," as if the time of being happy past, but her way is already set differently.

Sara Teasdale was trying to fight her depression and all the problems of life around her, however she lost this battle and was everywhere defeated, eventually she committed suicide. To choose her own death might be her own final way of taking control of her life, her bravest autonomous gesture, her own strange victory.

It is noteworthy that despite the shadows of death casted on Sara Teasdale's poems, her early concern with nature and the natural elements around her like the sea, the 


\section{Global Proceedings Repository \\ American Research Foundation}

ISSN 2476-017X

Available online at http://proceedings.sriweb.org

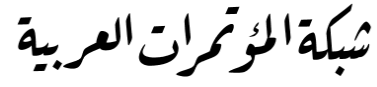

http://arab.kmshare.net/

AR F

Sun, the Moon, and the star endured. For her, "the sea, the stars, the moon, and all outward aspects of nature held strange and sublime wonder that her heart responded to with joy and this gift of rapturous response was hers until the end." (Carpenter, 1960, p. 332)

In "To the Sea" the poet is writing again about the sea, which is used to represent power, fulfillment and passion in her early poems, but now is seen differently:

Bitter and beautiful, sing no more;

Scarf of spindrift strewn on the shore,

Burn no more in the noon-day light,

Let there be night for me, let there be night. (Teasdale, 1937, p.212)

The mood of the poem is definitely different. There is no distress, but a calm

acceptance of the perfect peaceful end, that goes along with a strong belief that nature is

changeless and it is going to persist long after the death not only of the poet herself, but

all humanity:

The two that I love have walked with me.

I saw them change and my own heart change---

I cannot face the unchanging sea.

Her old passionate concern with nature with all its aspects last to the end. The last poem "There Will Be Rest", bringing the collection to a perfect close:

There will be rest, and sure stars shining

Over the roof-tops crowned with snow,

A reign of rest, serene forgetting,

The music of stillness holy and low. (Teasdale, 1937, p.214)

She is confident that "There will be rest", and the stars are going to keep shinning. The stars, to the very end, are still promising rest, stillness, and serenity. They always fascinated Sara Teasdale due to their unchanging radiance and brightness, and of course the peace they offered. Hence, the poet intended to make a world for herself, a peaceful and serene world and the stars definitely are going to be there shinning above the poet:

I will make this world of my devising

Out of a dream in my lonely mind.

I shall find the crystal of peace, and above me

Stars I shall find.

Though dark shadows possessed her spirit and her poems, she is so calm and accepting the end if not desiring it. She is so confident that she is to find her much desired peace, and only then, she is going to be free and fulfilled. Reading the poems, there is no grief, it is evident that the poet who constantly had been "singing from her heart, now when her heart was filled to overflowing with thoughts of imminent darkness, 


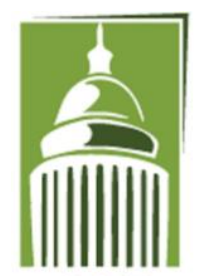

ARF

\section{Global Proceedings Repository \\ American Research Foundation}

ISSN 2476-017X

Available online at http://proceedings.sriweb.org

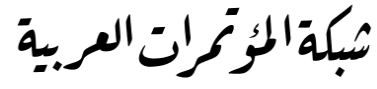

http://arab.kmshare.net/

she sang as movingly of death as she had sung of love". (Carpenter,1960, p. 347.)Composed and relieved, the poet is not only closing the collection, but her own life as well. Earlier in this collection, Sara Teasdale wrote, "My words are said, my way is clear." (Teasdale, 1937, p.213) Now it is so clear that she was determined and it was only a matter of time before she took her own life.

The wisdom she gradually and painfully gained disciplined her to cope with the searing pain and grief and to move on to make peace with the inevitable. The poet was increasingly drawn to death and moving inexorably and valiantly towards it. She was welcoming and desiring death with all the peace to come along with it. Her growing fascination is evident in her poems, mainly her later poems.

For Sara Teasdale, whose passionate concern and strong belief in nature impressively never ceased despite everything, the union with the natural surroundings and retaining a measure of independence is what all women should aspire to achieve. Her poems "attest to her belief that women should be autonomous, even when they fall in love. For strength, her poems urge women to avoid financial and emotional dependence on a husband in favor of union with sea and Sun and sky. Her strong feminist ideals influenced the poets Sylvia Plath, Edna St. Vincent Millay, and Elinor Wylie. "( Snodgrass, 2006, p. 531)

The poet was a source of inspiration for many poets of her generation and many generations to come. It is wildly believed that Sara Teasdale's success opened doors for more women such as Edna St.Vincent Millay, Margaret Widdemar, and Elinor Wylie, among others. In addition, she very generously supported her female peers and used her popularity to publish an anthology of their verse. (Champion, 2000, p. 345)

Two young women poets in particular, who turned to be among the greatest American women poets after Emily Dickinson and important voices of woman's poetry in the 20th century, admired the work of Sara Teasdale and they were highly influenced by her ideas and ideals; they are Sylvia Plath and Anne Sexton. The three women poets left behind great heritage, poems which enriched the enormous treasury of English poetry due to their beauty and clarity, honest and exquisite voicing of women's feelings, suffering and experiences. They all shared a fascination and romanticization of death and eventually they committed suicide after suffering from depression and succumbing under the heavy weight of their mental illness and all the problems faced them.

The whole idea of romanticizing death could be traced back to the great poet Christina Rossetti, who was fascinated and even romanticized the idea of death but she was not suicidal. Sara Teasdale highly admired Christina Rossetti's work and ideals. Early in her poetry, Sara Teasdale turned to the idea of death in 1911 when she wrote, "I Shall Not Care", and while her early poems were flamboyant and romantic, the later 


\section{Global Proceedings Repository \\ American Research Foundation}

ISSN 2476-017X

Available online at http://proceedings.sriweb.org

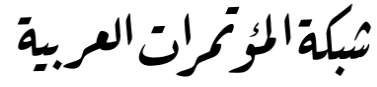

http://arab.kmshare.net/

AR F

suffused with the weight of the premonitions of death. As the poet matured, she abandoned her early girlish romantic dreams and the bright promises for better future, she realized that death is finality; it is the complete end for her suffering. Eventually, the only thing the poet really desired is to get the promised peaceful released death sure to bring. Despite this change in her poetry, her genius as lyricist never gets any lesser, but it was developed highly so that at the time of her death she really reached the height of her poetic achievement.

Another characteristic Sara Teasdale shared with Christina Rossetti is her reclusiveness, her tendency to withdraw from the world to create her poetry in nearly a complete seclusion. Sara Teasdale retreated after her divorce when her life, her marriage, and her career turned to be so demanding. She was trying to isolate herself and to focus on writing poetry and to get the autonomy and serenity she so desired, but this was not helping as her mental state declined and ultimately she committed suicide.

The loss of Sara Teasdale was a real tragedy; she was a real genius, a talented poet who used the simplest form in English poetry to convey her own hopes, feelings, beliefs, uncertainty, struggle, and anguish exquisitely. Death was only one theme among many she skillfully and beautifully tackled in her poetry. Her poetic artistry is best described by her biographer who wrote that if "one word could be used to describe the poetic artistry of Sara Teasdale, It would be the word pure. From a purity of spirit, she gave the world poems of pure music, pure emotion, and pure beauty. Even the suffering and resignation of later years could not mar this quality of purity; for as the darkness grew deeper, the true essence of the spirit shone even more luminously." (Carpenter,1960, p. 348)

Surely, her best and most beautiful work will live and her name will always be allied with the names of the "lyric singers of permanence --Sappho, Christina Rossetti, Housman. The haunting melodies and the golden words will not be lost or forgotten; they will endure as long as man is conscious of his own heart and spirit." (Carpenter,1960, p. 348)

Despite her tragic end, Sara Teasdale attained immortality through her poetry. Her death as dreadful and notorious as it was is a decision taken by a woman who deeply believed that: to live longer means to be more miserable. Despite the many factors that led to her final act of self-destruction, many still tend to romanticize her death considering her suicide as courageous act by a woman who valiantly chose what she thought to be the perfect closure of her life.

\section{References}




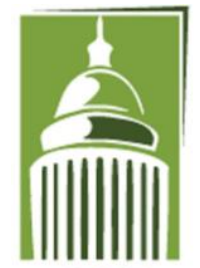

ARF

\section{Global Proceedings Repository \\ American Research Foundation}

ISSN 2476-017X

Available online at http://proceedings.sriweb.org

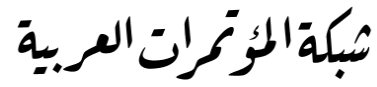

http://arab.kmshare.net/

Carpenter, Margaret Haley. 1960, Sara Teasdale: A Biography, Schulte Publishing, New York.

Champion, Laurie. 2000, American Women Writers, 1900-1945: A Bio-Bibliographical Critical Sourcebook, Greenwood Press, Westport.

Crawford, Robert ed. 2006, Contemporary Poetry and Contemporary Science. Oxford University Press, Oxford .

Drake, William. 1979, Sara Teasdale: Woman and Poet, Harper and Row Publishers, San Francisco.

Gilbert, Sandra M. 2005, "The Supple Suitor: Death, Women, Feminism, and (Assisted or Unassisted) Suicide", Tulsa Studies in Women's Literature, vol.24,no.2, 247-255.

Kaufman, James C. and John Baer. 2002, " I Bask in Dreams of Suicide: Mental Illness, Poetry, and Women ", Review of General Psychology, vol. 6, no. 3, 271-286.

Kaufman, James C. "The Sylvia Plath effect: Mental illness in eminent creative Writers". Journal of Creative Behavior,35, 2001: 37-50.

Kimmelman ,Burt ed. 2005, The Facts On File Companion to 20th-Century American Poetry, Facts On File, Inc., New York.

Kumin, Maxine. 1982,"Stamping a Tiny Foot against God: Some American Women Poets Writing between the Two Wars", The Quarterly Journal of the Library of Congress, vol.39, 48-61.

Mueller, Andrea. 2009, Metropolitan Town and Other Songs, Mystery, and The Years", published PhD Thesis, The Louisiana State University.

Rittenhouse, Jessie Belle. n.d., Sara Teasdale, Macmillan Company, New York.

Sexton, Anne. 2001, Complete Poems, Houghton Mifflin Company, .Boston.

Simonton, D. K. 1994, Greatness: Who Makes History and Why, Guilford Press, New York .

Snodgrass, Mary Ellen. 2006, Encyclopedia of Feminist Literature, Facts On File, Inc., New York.

Stack, Steven Stack and David Lester eds. Suicide and the Creative Arts. New York: Nova Science Publishers, Inc., 2009.

Swiontkowski, Gale. 2003, Imagining Incest: Sexton, Plath, Rich, and Olds on Life with Daddy, Susquehanna University Press, Selinsgrove.

Teasdale, Sara. 1995, Rivers to the Sea, Macmillan Co., New York . ,1937, The Collected Poems of Sara Teasdale ,Macmillan Co., New York. Walker, Cheryl . 1991, Masks Outrageous and Austere: Culture, Psyche, and Persona in Modern Women Poets, Indiana University Press, Bloomington. 